Research Article

\title{
Rabies and International Travellers: A Missing Link
}

\author{
Lalit Sankhe', Sneha Parve ${ }^{2}$, Akila P3
}

${ }^{1}$ Associate Professor, ${ }^{2,3}$ Department of Community Medicine, Grant Medical College and JJ Hospital, Mumbai, Maharashtra, India. DOI: https://doi.org/10.24321/2454.325X.202107

\section{I $\quad \mathbf{N} \quad \mathbf{F} \quad \mathbf{O}$}

\section{Corresponding Author:}

Sneha Parve, Department of Community

Medicine, Grant Medical College and JJ Hospital,

Mumbai, Maharashtra, India.

E-mail Id:

snehamaltiparve@gmail.com

Orcid Id:

https://orcid.org/0000-0003-0442-8736

How to cite this article:

Sankhe L, Parve S, Akila P. Rabies and International

Travellers: A Missing Link. Int J Preven Curat

Comm Med. 2021;7(2):9-13.

Date of Submission: 2021-06-09

Date of Acceptance: 2021-06-25

\section{$\begin{array}{llllllll}\mathbf{A} & \mathbf{B} & \mathbf{S} & \mathbf{T} & \mathbf{R} & \mathbf{A} & \mathbf{C} & \mathbf{T}\end{array}$}

Introduction: Rabies is a viral disease endemic in more than 150 countries and territories with highest exposure in Asia and Africa. It is found in all continent except Antarctica. Countries which are not at risk for travel related diseases like rabies, traveller's going there do not seek medical advice before travelling. In parts where rabies is still a problem, treatment may be in accessible.

Methodology: It was OPD based cross sectional study in Adult Vaccination Centre at tertiary care institute. From July to September 2020, the data was collected. Pretested questionnaire was assessed by interview method.

Results: We found that maximum travellers $69 \%$ were in the age group less than 30 years with mean age being 26 . Only $10 \%$ of traveller had history of animal bite. Among them $52 \%$ had dog bite followed by $47 \%$ cat bite while $53 \%$ had bleeding. $52 \%$ had not used any pre hospital procedure after bite. $21 \%$ had applied turmeric, 15\% applied slaked lime, while $10 \%$ had washed the wound with water and soap. $31 \%$ travellers travelled to South Africa. 97\% travellers have the idea that dog bite can transmit the disease.

Conclusion: Rabies pre-exposure vaccination should be offered to individuals traveling regularly to international destinations and who are at high risk of exposure to potentially rabid animal attacks.

Keywords: Rabies, International Traveller, Pre-Exposure Prophylaxis

\section{Introduction}

Rabies is a viral disease endemic in more than 150 countries and territories with highest exposure in Asia and Africa. It is found in all continent except Antarctica. ${ }^{1}$

In Africa there is estimated 21476 human death per year while they spend least on post exposure prophylaxis. ${ }^{2}$ In Asia, 33172 human death occur per year among which $59.9 \%$ of them occur in India alone. Along with Asia and
Africa it is endemic in Central and South America, Middle East with annual death rate of $229 .^{3}$

In Asia, Bangladesh, India, Myanmar, Pakistan is categorized as high endemic areas, Bhutan, Nepal, Srilanka as medium endemic while Thailand and Indonesia as low endemic areas. ${ }^{1}$ Countries which are not at risk for travel related diseases like rabies, traveller's going there do not seek medical advice before travelling. In parts where rabies is still a problem, treatment may be in accessible. Also, there 
are several factors identified in previous studies which affect the choice of traveller to get vaccinated like cost, time constraint and perspective on importance of vaccination.

Therefore, when a traveller from high endemic region to low endemic region or from rabies endemic country to no rabies country and there is dog bite there is high probability of mortality due to unavailability or inaccessibility of vaccines. Another possibility is even though dog is vaccinated in a zero-rabies country but he is having low immunity for the same, may transmit rabies via multiple bites causing human deaths locally.

Need of traveller to get vaccinated is of utmost important considering all other factors. WHO leads the collective "united against rabies to drive progress towards zero human death from dog mediated rabies by 2030". Mexico was the first country to have been validated by WHO in 2019 for eliminating human death from dog mediated rabies. Since the launch of global framework WHO has worked with FAO of UN to form global alliance for rabies control and partners to prepare a global strategic plan.

Keeping this in view we thought of doing study to understand felt need of travellers regarding vaccination against rabies who travel internationally. It will also help to, maintain eliminated status of different countries and ultimately will help to achieve noble initiative started by WHO.

\section{Methodology}

It was OPD based (setting) cross sectional study in Adult Vaccination Centre at tertiary medical college in metropolitian city. For quarter of time period from July to September 2020. Travellers visiting the OPD, after obtaining informed consent from study subject who fulfilled eligibility criteria data were included in the study. They were assessed by pretested questionnaire by interview method. An in-depth interview addressing two different parts were included. First part included information on socio demographic details and second part has knowledge attitude and perception about pre-exposure vaccination in travellers. Taking universal sampling as method of data collection all travellers attending OPD during the mentioned time period were included. Data was entered in Microsoft excel and was analysed using statistical package for software solution (SPSS 23.0). Appropriate statistical test were applied. Study was started only after IEC/ University approval considering Ethical/ ICMR guidelines. All the data was collected and kept confidential.

\section{Results}

We found that $90 \%$, was in the age group of less than 40 years. Very few $9.4 \%$ were in the age group above $40.66 .3 \%$ with male female ratio of 1.96 .

Most of the traveller $57 \%$ were educated up to secondary school followed by $39 \%$, who were graduate. About $40 \%$ travellers were educated up to graduate and above (Table 1 ).
Table I.Social Data of Travellers

\begin{tabular}{|c|c|c|}
\hline Age & No of Travellers & Frequency (\%) \\
\hline$<40$ years & 172 & 90.5 \\
\hline$>40$ years & 18 & 9.47 \\
\hline Sex & $(\mathrm{N}=190)$ & Frequency (\%) \\
\hline Male & 126 & 66.3 \\
\hline Female & 64 & 33.6 \\
\hline Education & $(\mathrm{N}=190)$ & Frequency $(\%)$ \\
\hline No formal schooling & 0 & 0 \\
\hline Primary school & 05 & 2.7 \\
\hline Secondary school & 109 & 57.36 \\
\hline Graduate & 75 & 39.47 \\
\hline Total & 190 & 100 \\
\hline
\end{tabular}

Figures in the parenthesis indicates percentage.

Table 2.Animal Bite Distribution among Travellers

\begin{tabular}{|c|c|c|}
\hline H/o animal bite & $\mathbf{N = 1 9 0}$ & Frequency (\%) \\
\hline Yes & 19 & 10 \\
\hline No & 170 & 89.5 \\
\hline Type of animal & $\mathbf{N = 1 9}$ & Frequency (\%) \\
\hline Dog & 10 & 52.6 \\
\hline Cat & 09 & 47.36 \\
\hline Monkey & 00 & 0 \\
\hline Other & 00 & 0 \\
\hline Type of animal & $\mathbf{N = 1 9}$ & Frequency (\%) \\
\hline Pet & 07 & 36.8 \\
\hline Stray & 12 & 63.15 \\
\hline Bleeding & $\mathbf{N = 1 9}$ & Frequency (\%) \\
\hline Yes & 9 & 47.36 \\
\hline No & 10 & 52.63 \\
\hline $\begin{array}{c}\text { Pre-hospital } \\
\text { procedure }\end{array}$ & $\mathbf{N = 1 9}$ & Frequency (\%) \\
\hline Wound Wash & 02 & 10.6 \\
\hline Turmeric & 04 & 21.05 \\
\hline Slaked Lime & 03 & 15.8 \\
\hline Nothing & 10 & 52.7 \\
\hline $\begin{array}{c}\text { Medical consultation } \\
\text { after bite }\end{array}$ & $\mathbf{N = 1 9}$ & Frequency (\%) \\
\hline Yes & 16 & 84.2 \\
\hline No & 03 & 15.7 \\
\hline
\end{tabular}

Figures in the parenthesis indicates percentage.

Only $10 \%$ of traveller had history of animal bite. Among them $52 \%$ had dog bite followed by $47 \%$ cat bite, while $53 \%$ had bleeding. $63 \%$ were stray among them. Maximum 
traveller 52\% had not used any pre hospital procedure after bite. $21 \%$ had applied turmeric, $15 \%$ applied slaked lime, while $10 \%$ had washed the wound with water and soap (Table 2).

Thirty one percent of travellers are travelling to South Africa while travelling to other countries was in the range of two percent. Among them maximum eighty percent travelled for business purpose followed by fifteen percent for academic purpose. Mean days of gap between pre travel encounter and departure is 8.89 with a standard deviation of 6.035 (Table 3).

Table 3.Distribution of Travellers' according to Country of Travel

\begin{tabular}{|c|c|}
\hline Region of countries & No of Travellers'(N) \\
\hline Western Asia & $46(24.2 \%)$ \\
\hline Eastern Africa & $38(20 \%)$ \\
\hline Central Africa & $16(8.42 \%)$ \\
\hline South Africa & $60(31.5 \%)$ \\
\hline North America & 03 (1.5\%) \\
\hline Northern Europe & $06(3.15 \%)$ \\
\hline South East Asia & 05 (2.63\%) \\
\hline Eastern Europe & 03 (1.05\%) \\
\hline West Africa & $13(6.84 \%)$ \\
\hline \multicolumn{2}{|c|}{ Reason for travel } \\
\hline Business/Job & $153(80.5 \%)$ \\
\hline Academic Purpose & $30(15.7 \%)$ \\
\hline Visit Relatives & $06(3.15 \%)$ \\
\hline Expatriation & $01(0.5 \%)$ \\
\hline Total & 190 \\
\hline
\end{tabular}

Figures in the parenthesis indicates percentage.

Table 4.Knowledge regarding Rabies among Travellers

\begin{tabular}{|c|c|}
\hline Preventable & $\begin{array}{c}\text { No. of patients (N=190) } \\
\text { (Frequency \%) }\end{array}$ \\
\hline Yes & $31(16.13 \%)$ \\
\hline No & $158(83.15 \%)$ \\
\hline Pre-exposure prophylaxis & No. of patients \\
\hline Yes & $50(26.3 \%)$ \\
\hline No & $140(73.6 \%)$ \\
\hline Treatment available & No. of patients \\
\hline Yes & $80(42.15 \%)$ \\
\hline No & $110(58 \%)$ \\
\hline Fatality & No. of patients \\
\hline Yes & $52(27.8 \%)$ \\
\hline No & $148(77.8 \%)$ \\
\hline
\end{tabular}

\begin{tabular}{|c|c|}
\hline $\begin{array}{c}\text { Need for pre-prophylaxis } \\
\text { before travel }\end{array}$ & Response (N=190) \\
\hline Yes & $53(27.9 \%)$ \\
\hline No & $137(72.1 \%)$ \\
\hline $\begin{array}{c}\text { Reason for not taking } \\
\text { prophylaxis }\end{array}$ & Response (N=190) \\
\hline Adverse reaction & $11(5.8 \%)$ \\
\hline Time constraints & $164(86.3 \%)$ \\
\hline Not necessary & $13(6.8 \%)$ \\
\hline Less beneficial & $02(1.05 \%)$ \\
\hline
\end{tabular}

We found that ninety seven percentage of traveller knew rabies as a disease while others were not aware. Ninety seven percentage knew bite as mode of transmission, forty two percent knew scratch as mode of transmission while only eight percent had an idea of licking as a mode of transmission. Eighty three percent were of the opinion that rabies is not preventable. Seventy three percent thought of taking pre-exposure prophylaxis as a need to prevent rabies. Fifty eight percent traveller were of the opinion that treatment is not available for rabies while remaining forty two percent were knowing that treatment is available. Seventy eight percent traveller thought that it is not fatal.

We found that Seventy two percent traveller do not think there is any need for pre-exposure prophylaxis while only twenty eight percent thought it was needed. Eighty six percent stated that time constraints is the reason for not taking prophylaxis while $6.8 \%$ felt it was not necessary six percent felt it can cause adverse reaction (Table 4).

Table 5.Knowledge regarding Animal Transmitting Rabies

\begin{tabular}{|c|c|c|c|c|c|}
\hline $\begin{array}{c}\text { Animal } \\
\text { transmitting } \\
\text { rabies }\end{array}$ & Dogs & Cats & Monkey & Bat & Others \\
\hline $\begin{array}{c}\text { Response } \\
\text { of traveller } \\
\text { (N=190) }\end{array}$ & 185 & 22 & 02 & 01 & \multirow{2}{*}{0} \\
\hline $\begin{array}{c}\text { Frequency } \\
(\%)\end{array}$ & 97.3 & 11.6 & 1.5 & 0.52 & \\
\hline
\end{tabular}

Figures in the parenthesis indicates percentage.

Ninety seven percent of travellers have the idea that dog bite can transmit the disease. Eleven percent thought of cats, one percent of monkey while almost negligible thought of it is bat transmissible (Table 5).

\section{Discussion}

We conducted an observational study on travellers who come to ARV OPD for Adult Vaccination before travel. We found that maximum travellers sixty nine percent were in the age group less than 30 years with mean age of travellers 
being 26. Almost forty percent were graduate and above.

We found out that only ten percent of traveller had history of animal bite. Among them fifty two percent had dog bite followed by forty seven percent cat bite, while fifty three percent had bleeding. Carrara $\mathrm{P}$ et al. found that the most common species were dogs (50\%) and non-human primates (19\%). Non-human primate related injuries resulted mainly from bites and rarely from scratches. When asked about animal encounters while traveling in rabies-risk countries, 105 mentioned dogs (53\%), 77 mentioned monkeys (39\%), 35 mentioned bats (17\%), and 30 mentioned cats (15\%). Sixty three were stray among them. At least 600 to 700 cases of rabies are diagnosed in domestic and wild animals in South Africa annually. The majority of these were stray dogs $(75 \%)$, followed by pets ( $11 \%)$, wild animals ( $3 \%)$, and others/unknown (10\%). ${ }^{5}$

Maximum traveller fifty two percent had not used any pre hospital procedure after bite. $21 \%$ had applied turmeric, fifteen percent applied slaked lime while ten percent had washed the wound with water and soap. Carrara P et al. stated during travel immediate washing of the injury with water and soap was only mentioned by three percent of individuals and self-disinfection with antiseptics by twenty one percent. ${ }^{5}$ A pre-travel encounter was recorded in forty five percent of the cases. ${ }^{5}$ Matthias et al stated that immediate washing of the injury with water and soap was mentioned by only three percent of individuals and self-disinfection with antiseptics by twenty one percent. ${ }^{7}$ Sudarshan MK et al. in their study found that approximately $60 \%$ of victims had resorted to indigenous treatment following animal bite. The approaches most commonly resorted to were magico-religious practices twenty nine percent followed by herbal therapy ten percent. Consulting unqualified local practitioner's six, percent Application of red chilli powder five percent. Application of turmeric powder two percent, other local application/ dressings seven percent. ${ }^{8}$

Thirty one percent travellers travelled to South Africa while travelling to other countries was in the range of two percent. Carrara P et al. in their study found Southeast Asia four percent and the rest of Asia two percent compared to Australia-New Zealand two percent, Africa one percent, Latin America less than one percent, North America less than one percent and Europe one percent. Among them eighty percent travelled for business purpose followed by fifteen percent for academic purpose. Philippe Gautret et al stated that most common reason for travel is tourism. ${ }^{5}$

Ninety seven percent of traveller knew rabies as a disease while others were not aware. Altmann $\mathrm{M}$ et al. stated fifty percent of traveller's were aware of the preventive vaccination. Ninety seven percent were knowing bite as mode of transmission, forty two percent knew scratch as mode of transmission while only eight percent had an idea of licking as a mode of transmission. Eighty three percent were of the opinion that rabies is not preventable. Seventy three percent thought of taking pre-exposure prophylaxis as a need to prevent rabies. Fifty eight percent travellers were of the opinion that treatment is not available for rabies while remaining forty two percent were knowing that treatment is available. Seventy eight percent traveller thought that it is not fatal. ${ }^{7}$

Ninety seven percent travellers have the idea that dog bite can transmit the disease. Eleven percent thought of cats, one percent of monkey while almost negligible thought of it is bat transmissible. We found that seventy two percent traveller do not think there is any need for pre-exposure prophylaxis while only twenty eight percent thought it was needed. Altmann $\mathrm{M}$ et al. forty two percent of travellers answered "yes" were ready to take preventive vaccination against rabies. ${ }^{7}$

Eighty six percent stated that time constraints is the reason for not taking prophylaxis while seven percent felt it was not necessary , six percent felt it can cause adverse reaction. Altmann $\mathrm{M}$ et al. stated that reasons for refusal of preventive vaccination were mainly low benefit/ risk for rabies fifty five percent, high cost twenty five percent, and adverse vaccine reaction eight percent. $^{7}$

\section{Conclusion}

Ten percent of traveller had history of animal bite of which fifty two percent had dog bite, forty seven percent cat bite while fifty three percent had bleeding. Fifty two percent had not used any pre-hospital procedure after bite. One fifth had applied turmeric, fifteen percent applied slaked lime while ten percent had washed the wound with water and soap. One third travellers travelled to South Africa. Majority of traveller knew rabies as a disease. Seventy two percent traveller do not think there is any need for pre-exposure prophylaxis while only twenty eight percent thought it was needed. Eighty six percent stated time constraints is the reason for not taking prophylaxis. We suggest that rabies pre-exposure vaccination should be offered beside mass awareness to individuals traveling regularly to international destinations and who are at high risk of exposure to potentially rabid animal attacks.

\section{Conflict of Interest: None}

\section{References}

1. https://www.who.int/health-topics/rabies

2. https://www.who.int/news-room/commentaries/ detail/new-global-strategic-plan-to-eliminate-dogmediated-rabies-by-2030 https://www.who.int/ southeastasia https://www.who.int/health-topics/ rabies\#tab=tab_1Gossner CM, Mailles A, Aznar I, Dimina E, Echevarria JE, Feruglio SL, Lange H, Maraglino 
FP, Parodi P, Perevoscikovs J, Van der Stede Y, Bakonyi T. Prevention of human rabies: A challenge for the European Union and the European Economic Area. Euro Surveill. 2020 Sep;25(38):2000158. [PubMed] [Google Scholar]

3. Carrara P, Parola P, Brouqui P, Gautret P. Imported human rabies cases worldwide, 1990-2012. PLoS NegI Trop Dis. 2013 May 2;7(5):e2209. [PubMed] [Google Scholar]

4. Marano C, Moodley M, Melander E, De Moerlooze L, Nothdurft HD. Perceptions of rabies risk: A survey of travellers and travel clinics from Canada, Germany, Sweden and the UK. J Travel Med. 2019 Feb 1;26(Suppl 1):S3-S9. [PubMed] [Google Scholar]

5. Altmann M, Parola P, Delmont J, Brouqui P, Gautret P. Knowledge, attitudes, and practices of french travellers from marseille regarding rabies risk and prevention. J Travel Med. 2009;16(2):107-11. [PubMed] [Google Scholar]

6. Sudarshan MK, Madhusudana SN, Mahendra BJ, Rao NS, Narayana DA, Rahman SA, Meslin FX, Lobo D, Ravikumar K. Assessing the burden of human rabies in India: results of a national multi-center epidemiological survey. Int J Infect Dis. 2007 Jan;11(1):29-35. [PubMed] [Google Scholar] 